Volume 10, Issue 2, Desember 2019, Pages. 176-192

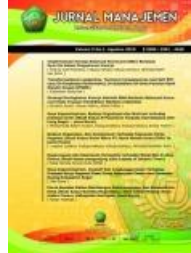

Jurnal Manajemen

(Edisi Elektronik)

Journal homepage: http://ejournal.uika-bogor.ac.id/index.php/manajemen/

e-ISSN: 2301-4628

\title{
Analisis Fraud Diamond Theory Dalam Mendeteksi Terjadinya Manajemen Laba Pada Laporan Keuangan Perusahaan
}

\author{
Himmatul Khairi ${ }^{a}$, M. Fany Alfarisi ${ }^{b}$ \\ Universitas Andalas, Padang \\ himmatulkhairi.au@gmail.com
}

\section{A R T I C L E IN F O}

DOI: $10.32832 / j m-u i k a . v 10 i 2.2552$

Article history:

Received:

03 Oktober 2019

Accepted:

21 Oktober 2019

Available online:

01 Desember 2019

\section{Keywords:}

Fraud, Fraud Diamond Theory, Earnings management, Financing Firm

\begin{abstract}
A B S T R A C T
In this paper we discuss the elements of fraud diamond theory against indications of earnings management in indonesia's financing firms for year 2014 to 2018. The independent variables are financial stability, institutional ownership, audit quality, effective monitoring, auditor changes, ratio total acruals to total assets, change of directors, and independent board of commissioners, while the dependent variable used is the manipulation of financial statements proxied by earnings management. This study used 75 samples taken from 15 companies listed on the Indonesia Stock Exchange in 2014-2018. This research was conducted with quantitative methods using secondary data. Data analysis uses multiple regression models based on panel data, using firm size, leverage and firm age as contol variable. The results indicate that there are three important variables in the analysis of financial manipulation, those are financial stability, ratio total acruals to total assets, and number of independent commissioners. These variables represent three elements in the diamond fraud theory, financial stability which is presenting pressure, ratio total acruals to total assets representing rationalization, and number of independent commissioners presenting competency.
\end{abstract}




\section{Introduction}

Perusahaan melakukan pengungkapan perusahaan (Corporate Disclosure) dengan tujuan untuk pengomunikasian kondisi perusahaan kepada investor luar (Healy \& Palepu, 2001). Komunikasi tersebut tidak hanya digunakan oleh pemegang saham dan investor untuk menganalisis investasi mereka, tetapi juga oleh para pemangku kepentingan lainnya, termasuk untuk informasi tentang kebijakan sosial dan lingkungan perusahaan (Farvaque, Refait-alexandre, \& Saïdane, 2012). Informasi keuangan diungkapkan dalam laporan keuangan, laporan pertanggungjawaban sosial dan laporan tata kelola perusahaan. Sesuai dengan Pernyataan Standar Akuntansi Keuangan No. 1 tahun 2017, karakteristik kualitas laporan keuangan adalah dapat dimengerti, relevan, dapat dibandingkan dan dapat diandalkan. Laporan dikatakan andal jika informasi yang terdapat dalam laporan keuangan tersebut telah bebas dari kesalahan yang merugikan, material, dan dapat diandalkan sebagai informasi jujur yang dapat disajikan.

Dalam praktik bisnis baik dalam skala nasional maupun multinasional, tidak dipungkiri banyak bermunculan kasus kecurangan-kecurangan (frauds) yang dilakukan perusahaan untuk tujuan-tujuan tertentu, salah satunya adalah kecurangan dalam pelaporan keuangan perusahaan (fraudulent financial reporting). Praktik kecurangan pada laporan keuangan semakin banyak dilakukan oleh pihak-pihak tertentu untuk kepentingan perusahaan. Kecurangan tersebut dapat berupa kesengajaan atau kelalaian yang direkayasa sedemikian rupa sehingga informasi keuangan dalam laporan perusahaan tidak mencerminkan keadaan yang sesungguhnya. Rekayasa tersebut dapat berupa penyajian yang tidak sesuai dengan pedoman atau peraturan akuntansi yang diterima umum yang bersifat material dan mempengaruhi pengambilan keputusan oleh pihak-pihak yang berkepentingan.

Baru-baru ini di tahun 2018, sebuah kasus kecurangan yang dilakukan oleh perusahaan pembiayaan dalam negeri menyita perhatian publik karena merugikan banyak pihak. Perusahaan tersebut adalah PT Sunprima Nusantara Pembiayaan atau dikenal dengan SNP Finance, perusahaan pembiayaan yang merupakan bagian dari perusahaan Columbia. Kasus ini merugikan banyak pihak seperti beberapa bank yang tersangkut paut dalam kasus ini karena menyalurkan kredit kepada tersebut, diantaranya adalah PT Bank Mandiri Tbk dengan penyaluran kredit mencapai Rp $4 \mathrm{~T}$ dan melibatkan KAP terafiliasi Deloitte sebagai auditor eksternalnya.

Fenomena-fenomena kecurangan baik yang terjadi pada perusahaan publik maupun non publik memunculkan pertanyaan seperti bagaimana sebenarnya perusahaan menjalankan perusahaannya, dapatkah mempercayai laporan keuangan yang diterbitkan perusahaan dan peran serta keahlian auditor (Rezaee, 2005). Pada banyak fenomena fraud, hal yang paling sering didapati adalah manipulasi laba atau disebut juga manajemen laba (Earning Manajemen). Fraud dalam laporan keuangan berkaitan dengan manipulasi laba yang dilakukan oleh manajemen (Hogan, Rezaee, Riley, \& Velury, 2008). Manajemen laba dilakukan dengan penerapan kebiajkan akuntansi untuk tujuan tertentu yang dilakukan oleh manajemen perusahaan (Summers \& 
Sweeney, John, 1998).

Dari segi perusahaan, fraud pada laporan keuangan menyebabkan informasi di dalam laporan keuangan menjadi tidak relevan dan salah saji material yang dapat menyebabkan kerugian pada pihak-pihak yang berkepentingan. Kondisi ini lebih jauh dapat menjerumuskan perusahaan pada rentetan masalah yang panjang, mulai dari pengambilan keputusan yang salah, kepercayaan dari investor yang semaki berkurang, hingga permasalahan dengan regulator baik itu masalah perpajakan maupun masalah hukum lainnya. Pihak manajemen perusahaan hendaknya meminimalisasi agar kondisi tersebut tidak terjadi di dalam perusahaan.

Untuk meminimalisasi bahkan mencegah terjadinya hal buruk akibat manipulasi data keuangan perusahaan, maka dapat dilakukan tindakan pendeteksian. Salah satu cara pendeteksian tersebut adalah dengan analisis perspektif segiempat kecurangan (Fraud Diamond), yang ditemukan oleh Wolfe dan Hermerson (2004). Teori ini merupakan penyempurnaan dari teori sebelumnya yaitu Fraud Triangle yang dikemukakan oleh Cressy tahun 1953. Keempat elemen tersebut dijadikan variable dalam penelitian ini adalah tekanan (pressure), kesempatan (opportunity), rasionalisasi (rationalization), dan kemampuan (competency).

\section{Literature Review}

\section{Teori Agensi (Agency Theory)}

Teori Agensi (Agency Theory) ditemukan oleh Michael C. Jensen dan William $\mathrm{H}$. Meckling (1976) yang menyatakan adanya kontrak atau perjanjian kerja sama yang yang kuat antara principal dan agent. Principal adalah pihak yang menanamkan modal dalam perusahaan dan mendelegasikan instruksi dalam pengoperasian perusahaan, sedangkan agent adalah pihak yang menerima instruksi dari principal untuk melaksanakan operasi perusahaan sesuai dengan amanat dari principal. Dalam hubungan ini akan ada asimetri informasi, yakni agen atau manajemen sewaktu-waktu memiliki informasi yang tidak diketahui oleh pemilik modal atau principal. Disini akan timbul benturan kepentingan, dimana pihak manajemen akan bertindak demi kepentingan pribadi dan tidak memaksimalkan kepentingan pemegang saham. Hal tersebut akan memancing timbulnya sifat dan keadaan yang dapat memancing terjadinya kecurangan.

\section{Teori Fraud (Fraud Theory)}

Albercht et al. (2011) menyatakan bahwa fraud merupakan hal yang bersifat umum dan memiliki banyak makna, yang terjadi karena kecerdikan manusia dan ditujukan untuk satu pihak untuk memperoleh keuntungan lebih dengan penyajian yang salah. Ada tiga teori utama Fraud yang telah ditemukan yakni adalah Fraud Triangle Theory, Fraud Diamond Theory dan Fraud Pentagon Theory. Pertama kali fraud theory dikemukakan oleh Donald R.Cressey di tahun 1953 yang diberi nama Fraud Triangle. Fraud Triangle menyatakan ada tiga faktor penyebab kecurangan, yakni pressure (tekanan), opportuniy (kesempatan) dan rasionalization (rasionalization). Fraud Triangle kemudian menjadi Fraud Diamond yang dikembangkan oleh Wolfe dan Hermanson di tahun 2004, dengan menambahkan satu faktor, yakni compentency (kompetensi) yang melandasi terjadinya kecurangan. Kemudian di tahun 2011, teori kecurangan disempurnakan oleh Crowe yang menambahkan satu faktor kecurangan lagi yang disebut Fraud Pentagon Theory, yang terdiri dari lima faktor yang melandasi terjadinya fraud. 


\section{Fraud Triangle Theory}

Pertama kali teori mengenai fraud dikemukan oleh Donald. R. Cressey (1953) yang menjabarkan terjadinya fraud dilandasi oleh tiga komponen utama yakni :

a. Pressure (Tekanan)

Pressure (Tekanan) diartikan sebagai masalah keuangan atau yang memotivasi seseorang untuk melakukan kecurangan. Pressure merupakan motivasi untuk melakukan dan menyembunyikan tindakan fraud. Seseorang dapat melakukan hal yang tidak terpuji karena adanya adanya kebutuhan mendesak yang harus terpenuhi seperti tekanan keuangan ataupun faktor eksternal lainnya.

b. Opportunity (Peluang)

Opportunity (Peluang) yakni kemampuan seseorang untuk melakukan kecurangan dalam sebuah perusahaan. Peluang terebut disebabkan karena pengawasan yang minimal dalam perusahaan. Disini, seseorang karyawan melihat dirinya memiliki kesempatan untuk melakukan kejahatan tanpa diketahui.

c. Rationalization (Rasionalisasi)

Rasionalisasi merupakan sikap pembenaran terhadap sebuah kecurangan. Hal ini dapat berarti bahwa saaat seseorang melakukan kecurangan atau pelanggaran, berdasarkan rasionalisasinya perbuatan tersebut bukan merupakan pelanggaran atau kecurangan. Cressey mendapati bahwa kecurangan yang ia pelajari umumnya merasionalisasi kejahatan mereka dengan memandangnya sebagai tindakan yang pada dasarnya nonkriminal, dapat dibenarkan, atau bagian dari tanggung jawab umum di mana mereka tidak sepenuhnya bertanggung jawab.

\section{Fraud Diamond Theory}

Fraud Diamond Theory dikembangkan oleh
Wolf dan Hermanson (2004) dengan menambahkan satu komponen yang melandasi terjadinya fraud, yakni Competency/Capability. Menurut Wolfe dan Hermanson, sifat dan kemampuan kepribadian seseorang juga berdampak pada kemungkinan kecurangan. "Opportunity opens the doorway to fraud, and incentive (pressure) and rationalization can draw a person toward it; but the person must have the capability to recognize the open doorway as an opportunity and to take advantage of it by walking through, not just once, but time and time again."

Crowe menekankan bahwa kompetensi memberikan pelaku kesempatan untuk mengubah niat melakukan kecurangan menjadi kenyataan. Selain itu, kemampuan individu, yang terlihat dari ciri-ciri pribadi dan kemampuan individu, dapat menjadi penyebab terjadinya kecurangan (Dorminey, 2012).

Dorminey (2012) menyatakan opportunity membuka pintu bagi kecurangan, insentif dan rasionalisasi membuat individu semakin yakin untuk melakukan kecurangan, namun individu tersebut harus memiliki kompetensi untuk menyadari peluang tersebut dan melakukan kecurangan serta menyembunyikannya.

\section{Earning Management (Manajemen Laba)}

Sampai saat ini, masih terdapat perbedaan pandangan manajemen laba, merupakan aktivitas legal atau tidak. Beberapa pihak menganggap manajemen laba bertentangan dengan prinsip akuntansi. Sementara yang lain menganggap manajemen laba sebagai praktik normal dalam menyiapkan laporan keuangan, terutama jika manajemen laba masih dalam batasan cakupan prinsip akuntansi. Earning Management atau manajemen laba merupakan penerapan kebijakan akuntansi dalam bentuk spekulasi yang dilakukan manajemen perusahaan untuk mencapai tujuan tertentu 
(Scott, 2003). Schipper (1989) menyatakan manajemen laba merupakan manajemen pengungkapan, yakni melakukan intervensi pada laporan keuangan yang bertujuan untuk memperoleh keuntungan pribadi. Tujuan tersebut dapat berupa upaya meningkatkan kemampuannya sendiri dan meningkatkan harga pasar perusahaan (Scott, 2012). Healy \& Wahlen, (1999), menyatakan bahwa manajemen laba dapat terjadi ketika manajemen menggunakan pertimbanganpertimbangan tertentu dalam pelaporan keuangan dan melakukan rekayasa dalam pencatatan pihak-pihak yang berkepentingan perusahaan. Selain itu manajemen laba juga bertujuan untuk mempengaruhi hasil kontrak yang bergantung pada angka akuntansi yang dilaporkan dalam laporan keuangan.

Kemampuan manajer untuk menggunakan pertimbangan dan kebijakan akuntansi memberikan mereka kekuatan untuk menentukan metode dan estimasi akuntansi yang diijinkan (Skinner \& Dechow, 2000). Salah satu cara manajemen laba adalah melalui akrual (Dechow et all, 1995). Akrual merupakan basis dalam akuntansi yang mengakui dan mencatat transaksi pada saat transaksi atau peristiwa tersebut terjadi (bukan hanya pada saat kas yang diterima atau dibayar). Dalam basis akuntansi akrual, semua kejadian atau transaksi ekonomis yang mengakibatkan perubahan posisi keuangan diakui baik melibatkan transaksi pembayaran dan penerimaan tunai maupun tidak sehingga semua pencatatan akuntansi adalah sesuai dengan peristiwa yang terjadi. Dalam kebijakan akrual terdapat dua komponen yakni komponen non-discretionary accruals (komponen akrual diluar kebijakan manajemen) dan discretionary accruals (komponen akrual yang berada dalam kebijakan manajemen melakukan intervensi dalam proses pelaporan keuangan).

\section{Pengembangan Hipotesis}

4 elemen dalam Fraud Diamond Theory diuji pengaruhnya terhadap manipulasi keuangan pada pelaporan keuangan sebuah perusahaan, masing-masing elemen diproksikan dengan dua variabel. Faktor Pressure akan diwakili oleh indikator financial stability (stabilitas keuangan) dan institusional ownership (kepemilikan institusional). Faktor opportunity akan diwakili oleh indikator quality of external audit dan effective monitoring. Faktor rasionalisasi akan diwakili oleh indikator change in eksternal auditor dan ratio total acrual to total asset. Faktor compentency akan diwakili oleh indikator change in board dan number of independen commisioner.

Kondisi keuangan yang stabil akan membuat nilai perusahan tersebut cenderung baik dalam perspektif pihak-pihak yang berkepentingan, baik itu kreditur, investor, maupun publik. Dengan demikian, manajer akan menghadapi tekanan untuk melakukan manipulasi dalam pelaporan keuangan ketika stabilitas ataupun profitabilitas keuangan terancam oleh situasi ekonomi, industri, atau entitas operasi (Skousen, Smith, \& Wright, 2008). Perusahaan yang tidak stabil dapat dilihat dari perubahan asetnya dibandingkan dengan aset pada tahun sebelumnya. Perusahaan yang mengalami goncangan terhadap keadaan ekonomi dan industri akan menyebabkan stabilitas keuangan yang tidak stabil dan menghadapi tekanan untuk melakukan Financial Fraud (Skousen et al., 2008).

Hipotesis 1 : Pressure dengan proksi Financial stability berpengaruh positif terhadap manajemen laba dalam laporan keuangan.

Kepemilikan institusional dalam institusi pembiayaan akan menjadi tekanan bagi 
institusi itu sendiri. Tekanan tersebut terjadi karena manajemen memiliki tanggung jawab yang lebih besar, tidak hanya tanggung jawab kepada individu pemilik saham tetapi juga untuk institusi yang memiliki komposisi saham lebih besar (Skousen et al., 2008). Selain itu, mengingat saham yang dimiliki oleh perusahaan yang lebih besar dari saham individu, itu mendorong manajemen untuk melakukan lebih banyak upaya agar tidak kehilangan pelanggan dan investor; salah satu caranya adalah 'memperindah' laporan keuangan melalui manipulasi laporan keuangan.

Hipotesis 2 : Pressure dengan proksi Institutional ownership berpengaruh negatif terhadap manajemen laba dalam laporan keuangan

Audit laporan keuangan dapat menjadi salah satu alat deteksi kecurangan yang dilakukan pihak perusahaan pada laporan keuangannya. Semakin baik kualitas audit yang dihasilkan memperlihatkan semakin kecil kesempatan untuk melakukan manipulasi informasi keuangan. Dalam Penelitian Francis (2004) mengungkapkan bahwa beberapa studi empiris menunjukkan bahwa manajemen laba dan laporan audit memberikan bukti yang kuat bahwa kantor akuntan publik Big Five memberikan laporan keuangan dengan kualiatas yang jauh lebih baik. Biaya audit yang lebih tinggi menyiratkan kualitas audit yang lebih tinggi, baik melalui lebih banyak upaya audit (lebih banyak jam) atau melalui keahlian yang lebih besar dari auditor (Francis, 2004).

Hipotesis 3 : Opportunity dengan proksi Quality of eksternal audit berpengaruh negatif terhadap manajemen laba dalam laporan keuangan

Fraud dapat terjadi sebagai akibat dari lemahnya fungsi pengawasan yang dilakukan oleh perusahaan sehingga memberi kesempatan kepada manajemen untuk melakukan manipulasi laporan keunagan yang terlihat pada manajemen laba (Skousen et al., 2008). Untuk menghindari praktik pelaporan keuangan yang curang oleh manajemen, perusahaan memerlukan unit pengawas yang mampu memantau operasi perusahaan, salah satunya adalah Komite Audit. Semakin tingginya proporsi komite audit, maka pengawasan yang dilakukan kepada manajemen akan semakin ketat dan kemungkinan terjadinya manajemen laba dapat diminimalisasi (Beasley, 2000).

Hipotesis 4 : Opportunity dengan proksi effective monitoring berpengaruh negatif terhadap manajemen laba dalam laporan keuangan

Rasionalisasi yakni mampu memberikan alasan atau pembenaran bahwa seseorang melakukan kecurangan karena hal yang wajar dan bukan merupakan hal yang salah. Rasionalisasi dapat diproksikan dengan perubahan auditor eksternal karena adanya indikasi upaya penghapusan jejak audit oleh auditor periode sebelumnya. Informasi yang menunjukkan adanya indikasi kecurangan, biasanya juga diketahui dari auditor. Hal ini sejalan dengan penelitian yang menyatakan untuk mengurangi kemungkinan deteksi kecurangan laporan keuangan oleh auditor, perusahaan akan melakukan pergantian auditor (Lou \& Wang, 2009). Summers dan Sweeny (1998) menunjukkan bahwa mekanisme perubahan auditor dapat digunakan untuk mengurangi kemungkinan deteksi kecurangan laporan keuangan.

Hipotesis 5 : Rationalization dengan proksi Change in Public Auditor Pergantian audit berpengaruh positif terhadap manajemen laba dalam laporan keuangan

Menurut Francis dan Krishnan (1999), prinsip akrual berhubungan dengan pertimbangan 
manajemen dan merupaan aksi rasionalisasi dalam pelaporan keuangan. Rasionalisasi merupakan penilaian subyektif manajemen perusahaan dan pengambilan keputusan tersebut tercermin dalam nilai akrual perusahaan (Skousen et al., 2008). Rasionalisasi yang diproksi oleh TATA (Total Acrual to Total Asset) berpengaruh pada manipulasi dalam laporan keuangan karena konsep akrual tersebut memungkinkan manajemen untuk dapat melakukan pertimbangan-pertimbangan pada transaksi yang berbasis akrual, salah satunya dengan melakukan pencatatan ketika transaksi terjadi meskipun belum terjadi pengeluaran atau penerimaan kas (Oktarigusta, 2016). Saat nilai discretionary accruals naik, dapat disimpulkan manipulasi laporan keuangan juga mengalami kenaikan.

Hipotesis 6 : Rationalization dengan proksi ratio akrual dan aset berpengaruh positif terhadap manajemen laba dalam laporan keuangan.

Crowe (2004) menekankan bahwa kompetensi memberikan pelaku kesempatan untuk mengubah niat melakukan kecurangan menjadi kenyataan. Kompentensi merupakan faktor yang bersifat kualitatif yang menunjukkan kemampuan seseorang dalam perusahaan sehingga seseorang melihat suatu kesempatan melakukan kecurangan. Dengan adanya perubahan direksi mengindikasikan adanya manipulasi karena akibat dari perubahan tersebut adalah adanya upaya dari manajemen untuk memperbaiki hasil dari kinerja direksi sebelumnya dengan mempercantik laporan keuangan perusahaan. Dengan perubahan ini diharapkan perusahaan dapat memliki performa yang lebih baik dari periode sebelumnya.

Hipotesis 7 : Competency dengan proksi Change in Board berpengaruh positif terhadap manajemen laba dalam laporan keuangan.

Fraud dapat diminimalkan dengan pengawasan yang yang lebih kompeten. Dewan independen diyakini memiliki kompetensi dalam usaha peningkatan efektivitas fungsi pengawasan dalam perusahaan sehingga kualitas laporan keuangan menjadi lebih baik dan terbebas dari bias. Masuknya komisaris independen dari luar perusahaan dapat meningkatkan efektivitas pengawasan dalam perusahaan untuk mencegah adanya manipulasi laporan keuangan. Hal ini sejalan dengan hasil yang menjelaskan peningkatan persentase dewan komisaris independen mempengaruhi secara signifikan tingkat kecurangan pelaporan keuangan (Beasley \& Salterio, 2001).

Hipotesis 8 : Competency dengan proksi Number of Independen Commisioner berpengaruh negatif terhadap manajemen laba dalam laporan keuangan

\section{Research Methods}

Penelitian didesain dengan menggunakan penelitian uji hipotesis, yang dilakukan dengan menggabungkan studi cross sectional dan time series (data panel). Populasi dalam penelitian ini adalah Perusahaan Pembiayaan yang terdaftar di Bursa Efek Indonesia untuk tahun 2014-2018. Teknik pemilihan sampel dilakukan dengan metode purposive sampling, dengan kriteria-kriteria sebagai berikut

1. Sampel merupakan perusahaan pembiayaan yang terdaftar di Bursa Efek Indonesia per tahun 2014 sampai dengan tahun 2018.

2. Sampel merupakan perusahaan pembiayaan yang menerbitkan laporan tahunan lengkap yang berisi laporan keuangan dan laporan audit kepada publik, 
laporan pertanggungjawaban sosial, dan laporan tata kelola perusahaan.

3. Perusahaan menyediakan data yang digunakan untuk menghitung variabel penelitian disajikan dengan lengkap.

\section{Variabel Dependen}

Variabel dependen yang akan digunakan dalam penelitian ini untuk mempresentasikan manipulasi informasi keuangan adalah manajemen laba. Variabel ini diproksikan dengan Discretionary Accrual. Discretionary Accrual dihitung dengan menggunakan Rumus Modified Jones Model. Rumus ini dipilih karena dapat melakukan pendeteksian manajemen laba yang lebih baik daripada model lainnya sesuai dengan hasil Dechow et al. (1995).

Rumus Modified Jones Model dihitung dengan cara sebagai berikut :

1. Menghitung TACit, dengan rumus sebagai berikut

$\mathrm{TAC}$ it $=$ Niit - CFOit

Dengan :

TAC it $=$ Total Akrual perusahaan i periode

Niit $=$ Net Income perusahaan $\mathrm{i}$ periode $\mathrm{t}$

CFOit $=$ Operating Cash Flow perusahaan $\mathrm{i}$ periode $\mathrm{t}$

2. Perhitungan discretionary accrual dengan menggunakan model Jones (1991) yang diestimasi dengan persamaan regresi sebagai berikut:

$$
\begin{aligned}
\text { TACit/Ait- }= & \beta 1(1 / \text { Ait }-1)+ \\
& \beta 2[(\Delta \text { REVit }) / \text { Ait- } 1]+ \\
& \beta 3(\text { PPEit/Ait- } 1)+\varepsilon i t
\end{aligned}
$$

Dengan :

Ait-1 = Total aset perusahaan $\mathrm{i}$ pada periode $\mathrm{t}-1$

$\Delta$ REVit $=$ Perubahan penjualan bersih perusahaan i pada periode $\mathrm{t}$

PPEit = Gross property, plant, and equipmen perusahaan i pada periode $\mathrm{t}$

cit $=$ Error

3. Dengan menggunakan koefisien regresi diatas, nilai non discretionary accrual (NDAit) dihitung dengan menggunakan rumus Jones (1991) yang dimodifikasi Dechow dkk. (1995), yaitu :

$$
\begin{aligned}
\text { NDAit }= & \beta 1(1 / \text { Ait }-1)+\beta 2(\Delta \text { Revt } / \text { Ait }-1- \\
& \Delta \text { Rect } / \text { Ait }-1)+\beta 3(\text { PPEt } / \text { Ait }-1)
\end{aligned}
$$

Dengan :

$\triangle$ RECit $=$ Perubahan piutang bersih perusahaan i pada periode $\mathrm{t}$

$\beta 1, \beta 2, \beta 3=$ Nilai koefisien yang diperoleh dari hasil regresi

4. Menghitung nilai discretionary akrual yang menjadi nilai manajemen laba

DAit $=($ TACit $/$ Ait-1 $)-$ NDAit

Dengan :

Dait = Discretionary Accruals perusahaan $\mathrm{i}$ periode $\mathrm{t}$

TACit $=$ Total Akrual perusahaan i periode $\mathrm{t}$

Ait-1 = Total asset perusahaan $\mathrm{i}$ periode t-1

NDAit $=$ Non Discretionary Accruals perusahaan $\mathrm{i}$ periode $\mathrm{t}$ 


\section{Variabel Independen}

\section{Financial Stability}

Dalam Skousen et al., (2009), untuk menelusuri financial stability sebuah perusahaan dapat dilakukan dengan melihat bagaimana pengelolaan asetnya dari tahun ke tahun (diberi simbol AC)

$$
\mathrm{AC}=\frac{\text { Total Aset }(\mathrm{t})-\text { Total Aset }(\mathrm{t}-1)}{\text { Total Aset }(\mathrm{t}-1)}
$$

\section{Institutional Ownership}

Institutional Ownership (diberi simbol IO) atau Kepemilikan institusional diproksikan dengan persentase kepemilikan institusi dalam struktur saham perusahaan. (Skousen et all., 2009)

$$
\mathrm{IO}=\frac{\text { Total saham yang dimiliki institusi }}{\text { Total saham yang beredar }}
$$

3. Quality of Audit Eksternal

Kualitas dari eksternal auditor (Diberi simbol QA) dalam menggambarkan opportunity (Tessa \& Harto, 2016) diproksikan dengan menggunakan variabel dummy, yakni Kode 1 jika menggunakan jasa audit KAP Big 4 dan kode 0 jika tidak menggunakan jasa audit KAP Big 4.

4. Effective Monitoring

Effective monitoring diproksikan dengan rasio jumlah dewan komisaris independen (diberi simbol ACOM) dihitung dari jumlah anggota komite audit yang terdapat dalam perusahaan sampel.

5. Change in Eksternal Auditor

Pergantian auditor eksternal (Diberi Simbol CPA) per tahunnya untuk menggambarkan rasionalization, diproksikan dengan menggunakan variabel dummy, yakni Kode 1 jika terjadi pergantian Kantor Akuntan
Publik selama tahun 2014-2018 dan kode 0 jika tidak terjadi penggantian Kantor Akuntan Publik.

6. Ratio Total Accruals to Total Aset

Rumus untuk menghitung rasio TATA berdasarkan Beneish (2012) sebagai berikut:

$$
\text { TATA }=\frac{\text { Total Accruals }}{\text { Total Assets }}
$$

Dengan Total akrual dikalkulasikan sebagai laba bersih perusahaan dikurangi arus kas operasi perusahaan (Skousen et al, 2009)

7. Change in Board Director

Pergantian direksi (Diberi simbol DC) per tahunnya untuk menggambarkan competency diproksikan dengan menggunakan variabel dummy, yakni Kode 1 jika terjadi pergantian direksi selama tahun penelitian dan kode 0 jika tidak terjadi penggantian direksi

\section{Number of Independen Commisioner}

Jumlah dewan komisaris independen (diberi simbol ICOM) untuk menggambarkan competency, dihitung dari jumlah komisaris independen dalam perusahaan sampel.

\section{Variabel Kontrol}

1. Firm Size (diberi simbol Size).

Besarnya informasi yang tersedia untuk investor dalam pengambilan keputusan dipengaruhi oleh ukuran sebuah perusahaan. Firm size $=$ Ln Total Asset

2. Leverage (diberi simbol Lev).

Besarnya rasio leverage, yang berarti besarnya tingkat pembiayaan menggunakan hutang, menjadi pemicu pihak manajemen melakukan tindakan manajemen laba karena pengaruh dari para debitur. 


\section{$\mathrm{LEV}=\underline{\text { Total Hutang }}$ Total Aset}

3. Firm Age (diberi simbol Age).

Umur perusahaan merupakan salah satu parameter yang bisa mewakili suatu perusahaan dalam satuan waktu. Semakin lama siklus perusahaan berlangsung, maka perusahaan akan lebih banyak memiliki pengalaman menjalankan kinerja, pengawasan, dan lebih memanfaatkan peluang bisnis dengan baik.

\section{Result}

\section{Objek Penelitian}

Berdasarkan kriteria pemilihan sampel, didapatkan 15 perusahaan pembiayaan yang memenuhi kriteria purposive sampling, sehingga observasi sebanyak 75 objek untuk lima tahun rentang penelitian.

\section{Statistik Deskriptif}

Pada tabel 1 statistik deskriptif variabel penelitian dapat diperoleh gambaran mengenai karakteristik data dari variabel-variabel penelitian. Data yang digunakan sudah terdistribusi normal dan telah melalui tahap uji asumsi klasik diantaranya uji multikolinieritas, heteroskedastisitas dan autokorelasi.
Tabel 1

Statistik Deskriptif Variabel Penelitian

\begin{tabular}{|l|r|r|r|r|}
\hline \multicolumn{1}{|c|}{ Var } & \multicolumn{1}{c|}{ Min } & Max & Mean & $\begin{array}{c}\text { Std. } \\
\text { Deviatio } \\
\text { n }\end{array}$ \\
\hline EM & $-0,269$ & 0,461 & 0,047 & 0,142 \\
\hline AC & $-0,418$ & 0,514 & 0,070 & 0,177 \\
\hline IO & 0,499 & 0,954 & 0,767 & 0,120 \\
\hline QA & 0 & 1 & 0,57 & 0,498 \\
\hline ACOM & 1 & 4 & 2,96 & 0,584 \\
\hline CPA & 0 & 1 & 0,12 & 0,327 \\
\hline TATA & $-0,940$ & 0,303 & $-0,015$ & 0,211 \\
\hline DC & 0 & 1 & 0,51 & 0,503 \\
\hline IC & 0,250 & 0,600 & 0,420 & 0,084 \\
\hline SIZE & 24,66 & 31,08 & 28,53 & 1,597 \\
& 1 & 1 & 0 & \\
\hline LEV & 0,014 & 8,957 & 3,071 & 2,366 \\
\hline AGE & 9 & 46 & 27,80 & 8,520 \\
\hline
\end{tabular}

Sumber : Data sekunder yang diolah

\section{Uji Asumsi Klasik}

Uji Asumsi Klasik yang dilakukan telah memenuhi asumsi-asumsi model regresi yang diperlukan, tidak bias dan memiliki kesalahan (error) paling minimum.

\section{Uji Normalitas}

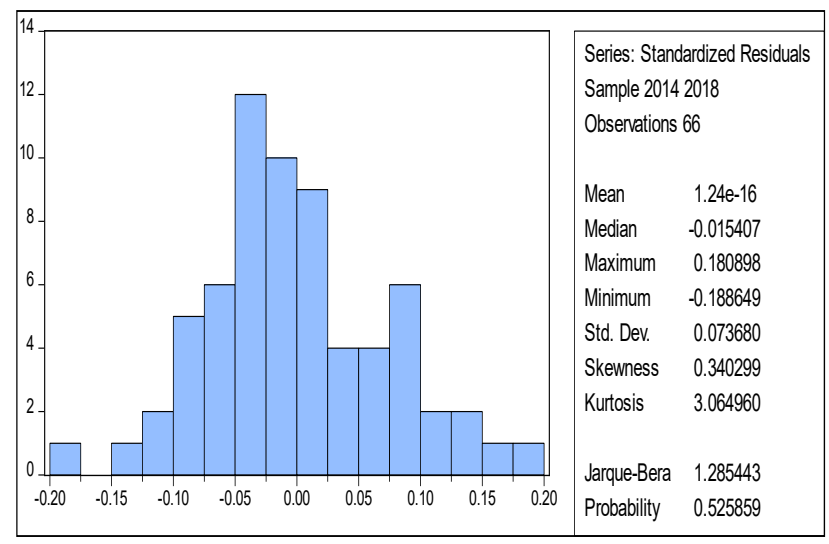

Gambar 1. Hasil Uji Normalitas

Berdasarkan pengujian normalitas residual diperoleh nilai probability sebesar 0.528 untuk residu variabel. Sehingga dapat disimpulkan bahwa seluruh variabel penelitian bernilai lebih 
besar dari 0.05 dan memenuhi syarat uji normalitas, artinya seluruh data penelitian telah berdistribusi normal dan pengolahan data layak dilakukan.

\section{Uji Multikolinieritas}

Tabel 2

Hasil Uji Multikolianeritas

\begin{tabular}{|c|r|r|r|}
\hline Variable & Variance & \multicolumn{1}{c|}{ VIF } & Ketentuan \\
\hline $\mathrm{X} 1$ & 0.011 & 3,644 & $\leq 10$ \\
\hline $\mathrm{X} 2$ & 0.020 & 2,712 & $\leq 10$ \\
\hline $\mathrm{X} 3$ & 0.000 & 2,335 & $\leq 10$ \\
\hline $\mathrm{X} 4$ & 0.000 & 1,218 & $\leq 10$ \\
\hline $\mathrm{X} 5$ & 0.001 & 1,179 & $\leq 10$ \\
\hline $\mathrm{X} 6$ & 0.010 & 3,523 & $\leq 10$ \\
\hline $\mathrm{X} 7$ & 0.000 & 1,149 & $\leq 10$ \\
\hline $\mathrm{X} 8$ & 0.033 & 2,280 & $\leq 10$ \\
\hline $\mathrm{X} 9$ & 0,000 & 2,162 & $\leq 10$ \\
\hline $\mathrm{X} 10$ & 0,000 & 2,275 & $\leq 10$ \\
\hline $\mathrm{X} 11$ & 0,000 & 1,385 & $\leq 10$ \\
\hline
\end{tabular}

Sumber : Data sekunder yang diolah

Dari tabel 2, nilai VIF pada masing-masing variabel independen kurang dari 10. Berdasarkan hal tersebut, maka masing-masing variabel independen dinyatakan tidak terjadi gejala multikolinearitas dan antarvariabel independen tidak memiliki korelasi.

\section{Uji Heteroskedastisitas}

Tabel 3

Hasil Uji Heteroskedastisitas

\begin{tabular}{|l|l|l|l|}
\hline Model & Coefficients & Model & Nilai \\
\hline F-statistic & 0,953 & $\begin{array}{l}\text { Prob. } \\
\text { F(11,54) }\end{array}$ & 0,498 \\
\hline $\begin{array}{l}\text { Obs*R- } \\
\text { squared }\end{array}$ & 10,734 & $\begin{array}{l}\text { Prob. Chi- } \\
\text { Square(11) }\end{array}$ & 0,465 \\
\hline $\begin{array}{l}\text { Scaled } \\
\text { explained } \\
\text { SS }\end{array}$ & 8,884 & $\begin{array}{l}\text { Prob. Chi- } \\
\text { Square(11) }\end{array}$ & 0,632 \\
\hline
\end{tabular}

Sumber : Data sekunder yang diolah

Berdasarkan hasil pengujian heteroskedastisitas dengan menggunakan uji
Glejser, terlihat bahwa koefisien probability Obs*R-squared sebesar 10,7345> 0.05 dan nilai Prob. Chi-Square(11) sebesar $0.46583>$ 0.05 maka dapat disimpulkan bahwa masingmasing variabel penelitian yang dibentuk kedalam sebuah model regresi data panel telah terbebas dari gejala heteroskedastisitas.

\section{Uji Heteroskedastisitas}

Tabel 4

Hasil Uji Autokorelasi

\begin{tabular}{|l|l|l|}
\hline Durbin Watson Stat & $\mathrm{dL}$ & $\mathrm{dU}$ \\
\hline 1,991 & 1,203 & 2,020 \\
\hline
\end{tabular}

Dari tabel 4 tersebut dapat diketahui nilai Durbin-Watson stat tabel Durbin-Watson semua variabel independen berada di daerah korelasi positif yakni DU < DW < 4-DU. Jadi dapat disimpulkan bahwa seluruh variabel pada penelitian yang berbasis data panel ini tidak terjadi autokorelasi.

\section{Regresi Berganda berbasis Data Panel}

Selanjutnya dalam penggunaan model Regresi data panel, model yang paling layak digunakan adalah fixed effext model setelah melalui uji pemilihan model data panel (Uji Chouw dan Uji Hausman). Dengan hasil sebagai berikut : 
Tabel 2

Regresi Data Panel Model Fixed Effect

\begin{tabular}{|c|c|c|c|c|}
\hline Var & $\begin{array}{c}\text { Coeffi } \\
\text { cient }\end{array}$ & $\begin{array}{l}\text { Std. } \\
\text { Error }\end{array}$ & $\begin{array}{c}\mathbf{t}- \\
\text { Statistic }\end{array}$ & Prob. \\
\hline $\mathrm{C}$ & 3,279 & 1,921 & 1,706 & 0,095 \\
\hline $\mathrm{AC}$ & 0,281 & 0,102 & 2,738 & 0,009 \\
\hline IO & $-0,199$ & 0,343 & $-0,580$ & 0,564 \\
\hline QA & 0,023 & 0,059 & 0,393 & 0,696 \\
\hline $\mathrm{ACOM}$ & $-0,003$ & 0,022 & $-0,174$ & 0,862 \\
\hline CPA & 0,022 & 0,035 & 0,619 & 0,539 \\
\hline TATA & 0,518 & 0,102 & 5,051 & 0,000 \\
\hline $\mathrm{DC}$ & 0,009 & 0,021 & 0,455 & 0,651 \\
\hline IC & $-0,546$ & 0,248 & $-2,195$ & 0,034 \\
\hline SIZE & $-0,138$ & 0,071 & $-1,945$ & 0,058 \\
\hline LEV & 0,047 & 0,011 & 3,952 & 0,000 \\
\hline AGE & 0,034 & 0,008 & 4,080 & 0,000 \\
\hline $\begin{array}{l}\mathrm{R} \text { - } \\
\text { squared }\end{array}$ & 0,868 & \multicolumn{2}{|c|}{$\begin{array}{l}\text { Mean dependent } \\
\text { var }\end{array}$} & 0,053 \\
\hline $\begin{array}{l}\text { Adjusted } \\
\text { R- } \\
\text { squared } \\
\end{array}$ & 0,786 & \multicolumn{2}{|c|}{$\begin{array}{l}\text { S.D. dependent } \\
\text { var }\end{array}$} & 0,145 \\
\hline $\begin{array}{l}\text { S.E. of } \\
\text { regresion }\end{array}$ & 0,067 & \multicolumn{2}{|c|}{$\begin{array}{ll}\begin{array}{l}\text { Akaike } \\
\text { criterion }\end{array} & \text { info } \\
\end{array}$} & $-2,276$ \\
\hline $\begin{array}{l}\text { Sum } \\
\text { squared } \\
\text { resid }\end{array}$ & 0,180 & \multicolumn{2}{|c|}{$\begin{array}{l}\text { Schwarz } \\
\text { criterion }\end{array}$} & $-1,413$ \\
\hline $\begin{array}{l}\text { Log } \\
\text { likelihod }\end{array}$ & 101,11 & \multicolumn{2}{|c|}{$\begin{array}{l}\text { Hannan-Quinn } \\
\text { criter. }\end{array}$} & $-1,935$ \\
\hline $\begin{array}{l}\text { F- } \\
\text { statistic }\end{array}$ & 10,57 & \multicolumn{2}{|c|}{$\begin{array}{l}\text { Durbin-Watson } \\
\text { stat }\end{array}$} & 3,018 \\
\hline $\begin{array}{l}\text { Prob(F- } \\
\text { statistic) }\end{array}$ & 0,00 & & \\
\hline
\end{tabular}

Sumber : Data sekunder yang diolah

Dari hasil pengujian dengan menggunakan variabel kontrol, dapat disusun persamaaan regresi berganda sebagai berikut :

\section{$\mathrm{EM}=3,279+0,281 \mathrm{AC}-0,19910+$ 0,023QA - 0,003ACOM + 0,022CPA + 0,518TATA - 0,009DC $-0,546 I C-0,013 S I Z E+$ 0,047LEV + 0,034AGE + e}

Untuk nilai Adjusted $R$-Square $\left(\mathrm{R}^{2}\right)$ yang menunjukkan kemampuan model menerangkan variasi dari independent variable. Dari tabel 2, terlihat bahwa nilai Adjusted $R$ Square bernilai 0,7865 yang menunjukkan bahwa 78,65\% variabel dependen dapat dijelaskan oleh variabel independen dan varabel kontrol dalam penelitian ini dengan baik, sedangkan 21,35\% dijelaskan oleh variabel variabel lain yang tidak dimasukkan dalam penelitian ini.

Untuk hasil uji f-statistik, yakni mengetahui secara bersama-sama apakah variabel independen berpengaruh secara signifikan atau tidak terhadap variabel dependen, diperoleh tingkat signifikansi semua variabel dependen sebesar 0.000, yang lebih kecil dari nilai $\alpha=0,05$. Artinya variabel independen berpengaruh secara signifikan terhadap variabel dependen. Dapat disimpulkan bahwa model memenuhi Goodness of Fit, maka model regresi dalam penelitian ini dapat digunakan untuk memprediksi tingkat manajemen laba atau dengan kata lain bahwa variabel independen secara bersama-sama berpengaruh terhadap variabel dependen.

Dari hasil Uji t-statistik yang digunakan untuk membuktikan pengaruh tiap variabel independen secara individu (parsial) terhadap variabel dependen, didapatkan variable yang lulus uji signifikansi kecil dari 0,05 adalah variabel Financial Stability, Ratio Total Acrual to Total Asset dan Number of Independen Commisioner.

\section{Pembahasan Hasil Penelitian}

Sesuai dengan Hipotesis 1, elemen Pressure yang diwakili dengan financial stability berpengaruh positif terhadap manajemen laba dalam laporan keuangan. Dalam penelitian ini, financial stability diproksikan dengan perubahan aset perusahaan dari periode tahun sebelumnya. Berdasarkan hasil pengujian $t$ statistic didapat perubahan aset memiliki nilai $t$ hitung 2,738 dengan probabilitas signifikansi sebesar 0,009. Hal tersebut menunjukkan bahwa nilai signifikansi t-statistic yang lebih kecil 
dari $0,05(p>0,05)$. Nilai positif pada koefisien regresi menunjukkan hubungan searah antara variabel stabilitas keuangan dengan manipulasi laporan keuangan, yang berarti semakin besar perubahan aset perusahaan, maka semakin besar tingkat manipulasi laporan keuangan. Level signifikan 0,009 yang kurang dari 0,05 berarti hipotesis diterima, dapat disimpulkan bahwa financial stability yang diproksi dengan perubahan aset memiliki pengaruh positif yang signifikan terhadap manajamen laba. Hal ini berarti semakin semakin besar rasio perubahan total aset suatu perusahaan, maka semakin tinggi potensi perusahaan untuk melakukan manipulasi laporan keuangan, terlepas dari dari adanya kondisi luar biasa yang terjadi dalam perusahaan, seperti peningkatan investasi, penambahan aset tetap secara dramastis ataupun suntikan dana dari debitur. Kondisi perusahaan yang tidak stabil ini bisa menjadi pressure bagi manajemen karena kinerja perusahaan terlihat menurun di mata publik.

Sesuai dengan Hipotesis 2, elemen Pressure yang diwakili dengan institutional ownership berpengaruh negatif terhadap manajemen laba dalam laporan keuangan Berdasarkan hasil pengujian hipotesis kepemilikan institusi memiliki nilai t hitung sebesar $-0,580$ dengan probabilitas signifikansi sebesar 0,586. Hal tersebut menunjukkan bahwa nilai signifikansi yang lebih besar dari $0,05(\mathrm{p}>0,05)$ yang berarti variabel institutional ownership tidak memiliki pengaruh yang signifikan terhadap manajamen laba. Meskipun kepemilikan institusional dalm perusahaan cukup tinggi, namun tidak menjadi tekanan bagi manajemen perusahaan. Kepemilikan institusional menunjukkan bahwa dalam perusahaan sampel telah ada kejelasan pemisahan antara pemegang saham institusional dan manajemen perusahaan. Adanya pemisahan yang jelas dalam perusahaan menyebabkan manajemen tidak memiliki cukup kemam- puan untuk melakukan manipulasi laporan keuangan.

Sesuai dengan Hipotesis 3, elemen Opportunity yang diwakili dengan Audit Quality berpengaruh negatif terhadap manajemen laba dalam laporan keuangan. Berdasarkan hasil pengujian hipotesis didapat kualitas audit memiliki nilai $\mathrm{t}$ hitung 0,393 dengan probabilitas signifikansi sebesar 0,692. Hal tersebut menunjukkan nilai signifikansi yang lebih besar dari 0,05 ( $\mathrm{p}>0,05)$ sehingga disimpulkan bahwa Audit Quality tidak memiliki pengaruh yang signifikan terhadap manajamen laba. Hasil penelitian ini bertentangan dengan penelitian yang dilakukan oleh Lennox dan Pittman (2010) yang menyatakan bahwa kualitas audit eksternal berpengaruh terhadap manipulasi laba. Namun hasil pada penelitian ini mendukung penelitian yang telah dilakukan oleh Tessa dan Harto (2016), dan Siddiq (2017) yang menyatakan bahwa kualitas audit eksternal tidak berpengaruh terhadap manajemen laba. Hal ini terjadi karena peran yang sama dari auditor eksternal baik KAP Big Four maupun KAP NonBig Four dalam melakukan audit laporan keuangan kliennya. Sehingga tidak ada perbedaan yang besar pada sumber daya manusia diantara KAP Big Four maupun KAP NonBig Four. Serta dari hasil penelitian ini, perusahaan sampel walaupun tidak di audit oleh perusahaan KAP berafiliasi bigfour, namun diaudit oleh KAP yang masuk dalam list big ten di Indonesia seperti KAP RSM, Grant Thornton, BDO dan Crowe Horwath. Sehingga dapat diambil kesimpulan bahwa auditor eksternal dalam KAP big ten juga memiliki kualitas audit yang tidak kalah bersaing dari KAP big four.

Sesuai dengan Hipotesis 4, elemen Opportunity yang diwakili dengan effective monitoring berpengaruh negatif terhadap 
manajemen laba dalam laporan keuangan. Berdasarkan hasil pengujian hipotesis didapat efektifitas pengawasan memiliki nilai t hitung 0,017 dengan probabilitas signifikansi sebesar 0,862 . Hal tersebut menunjukkan nilai signifikansi yang lebih besar dari $0,05(\mathrm{p}>0,05)$ yang berarti variabel independen tidak memiliki pengaruh terhadap variabel dependen. Dapat disimpulkan bahwa hipotesis ditolak, effective monitoring tidak memiliki pengaruh positif yang signifikan terhadap manajamen laba. Secara umum, kehadiran dewan komite audit akan memberikan jaminan kepada pengawasan perusahaan yakni pemantauan yang semakin mandiri dan obyektif bagi perusahaan. Namun dalam penelitian ini jumlah dewan komite audit belum memberikan jaminan untuk meningkatkan kontrol operasional perusahaan.

Sesuai dengan Hipotesis 5, elemen Rasionalization yang diwakili dengan change in eksternal auditor mempunyai pengaruh positif terhadap manajemen laba dalam laporan keuangan Berdasarkan hasil pengujian hipotesis didapat pergantian auditor eksternal memiliki nilai t hitung 0,619 dengan probabilitas signifikansi sebesar 0,539. Hal tersebut menunjukkan nilai signifikansi yang lebih besar dari 0,05 ( $\mathrm{p}>0,05)$ sehingga disimpulkan bahwa change in eksternal auditor tidak memiliki pengaruh yang signifikan terhadap manajamen laba. Penggantian auditor eksternal tidak membuktikan pengaruhnya terhadap tindakan manipulasi dari laporan keuangan. Perusahaan mengganti auditor eksternal bisa saja karena tidak puas dengan kinerja auditor eksternal pada periode sebelumnya dan ingin mendapatkan hasil audit yang lebih baik dengan pergantian auditor eksternal yang baru.

Sesuai dengan Hipotesis 6, elemen Rasionalization yang diwakili dengan ratio total acruals to total assets mempunyai pengaruh positif terhadap manajemen laba dalam laporan keuangan Berdasarkan hasil pengujian hipotesis didapat rasio TATA memiliki nilai t hitung 5,051 dengan probabilitas signifikansi sebesar 0,000. Hal tersebut menunjukkan nilai signifikansi yang lebih kecil dari 0,05 ( $\mathrm{p}<0,05)$ sehingga dapat disimpulkan bahwa ratio acruals to assets memiliki pengaruh positif yang signifikan terhadap manajamen laba. Nilai akrual perussahaan akan bervariasi tergantung pada keputusan manajemen terkait kebijakan tertentu. Manajemen dapat memainkan transaksi-transaksi akrual untuk mendapatkan nilai yang diharapkan pada laporan keuangan, sehingga akrual dapat digunakan oleh manajemen untuk membenarkan tindakan manipulasi. Dengan kata lain, nilai akrual berpotensi besar digunakan manajemen untuk memanipulasi laporan keuangan. Penelitian ini konsisten dengan penelitian Lou dan Wang (2009) dan Sihombing dan Rahadjo (2014), tetapi bertentangan dengan penelitian Skousen et. al (2009).

Sesuai dengan Hipotesis 7, elemen competency yang diwakili change in board berpengaruh positif terhadap manajemen laba dalam laporan keuangan. Berdasarkan hasil pengujian hipotesis didapat perubahan direksi memiliki nilai t hitung 0,455 dengan probabilitas signifikansi sebesar 0,651. Hal tersebut menunjukkan nilai signifikansi yang lebih besar dari 0,05 ( $\mathrm{p}>0,05)$ sehingga dapat disimpulkan bahwa change in board tidak memiliki pengaruh yang signifikan terhadap manajamen laba. Perubahan direksi perusahaan tidak dapat membuktikan indikasi tindakan manipulasi pada laporan keuangan perusahaan. Perubahan dewan direksi dalam perusahaan yang dijelaskan dalam laporan tahunan dapat terjadi karena pengalihan wewenang dan hasil RUPS. Perubahan yang dilakukan oleh perusahaan didorong oleh keinginan untuk meningkatkan 
kinerja perusahaan dari periode sebelumnya.

Sesuai dengan Hipotesis 8, elemen competency yang diwakili number of Independen Commisioner berpengaruh negatif terhadap manajemen laba dalam laporan keuangan. Berdasarkan hasil pengujian hipotesis didapat jumlah komisaris independen memiliki nilai t hitung sebesar -2,195 dengan probabilitas signifikansi sebesar 0,034 . Hal tersebut menunjukkan nilai signifikansi yang lebih kecil dari $0,05(\mathrm{p}<0,05)$ sehingga dapat disimpulkan bahwa number of Independen Commisioner memiliki pengaruh yang positif dan signifikan terhadap manajamen laba. Hasil penelitian ini menunjukkan bahwa selain penempatan atau penambahan anggota dewan komisaris independen adalah untuk memenuhi ketentuan BEI yang mewajibkan jumlah komisaris independen setidaknya memiliki persentase $30 \%$ dari total jumlah komisaris yang ada, hal ini juga menunjukkan bahwa keberadaan komisaris independen dengan kemampuan dan kompetensi yang dimilikinya memiliki pengaruh terhadap tindakan manipulasi informasi dalam laporan keuangan. Penelitian ini didukung oleh Beasley et al. (2000), Beasley (1996), Dechow et al. (1996) dan Dunn (2004) dalam Skousen al. (2009) yang mengamati bahwa perusahaan perusahaan yang tidak melalukan manipulasi keuangan memiliki komisaris independen dengan jumlah yang lebih banyak dibandingkan dengan perusahaan yang konsisten melakukan manipulasi pada laporan keuangan.

\section{Conclusion \& Suggestion}

Elemen-elemen Fraud Diamond Theory yang digunakan untuk mendeteksi manajemen laba pada pelaporan keuangan pada perusahaan pembiayaan yang terdaftar di BEI periode 2014-2018, dapat diambil kesimpulan bahwa variabel yang mewakili elemen Fraud
Diamond Theory, yakni faktor pressure diwakili oleh indikator financial stability (stabilitas keuangan) dan institusional ownership (kepemilikan institusional), faktor opportunity diwakili oleh indikator quality of external audit (kualitas audit) dan jumlah komite audit, faktor rasionalization diwakili oleh indikator pergantian auditor eksternal dan rasio total akrual terhadap total aset, dan faktor compentency diwakili oleh indikator pergantian dewan direksi dan jumlah dewan komisaris independen, bersama-sama secara simultan mempunyai pengaruh yang signifikan dengan variabel kontrol terhadap manajemen laba dan dapat menjelaskan tindakan manajemn laba sebesar 78,65\%, sedangkan $21,35 \%$ dipengaruhi oleh faktor lain yang tidak terdapat dalam penelitian ini.

Sedangkan pengaruh elemen Fraud Diamond secara independen menberikan hasil bahwa terdapat 3 elemen yang memberikan pengaruh terhadap manipulasi keuangan. Ketiga elemen tersebut yaitu elemen Pressure yang diwakili oleh proksi Financial stability, elemen rasionalization yang diwakili oleh rasio Total akrual terhadap total aset dan elemen compentency diwakili oleh indikator jumlah dewan komisaris independen yang memiliki pengaruh positif dan signifikan terhadap manajemen laba dalam laporan keuangan perusahaan. Sedangkan elemen lainnya, yakni faktor pressure yang diwakili dengan proksi institusional ownership (kepemilikan institusional), faktor opportunity diwakili oleh indikator quality of external audit (kualitas audit) dan jumlah komite audit, faktor rasionalization diwakili oleh indikator pergantian auditor eksternal dan faktor compentency diwakili oleh indikator pergantian dewan direksi tidak memberikan pengaruh yang signifikan terhadap manajemen laba dalam laporan keuangan perusahaan. 


\section{Keterbatasan dan Saran}

Keterbatasan dari penelitian ini diantaranya adalah proksi dari masing-masing elemen teori kecurangan belum memberikan hasil yang maksimal. Dari nilai R Square sebesar 78,65\%, berarti ada variabel lain sebesar 21,35\% mempunyai pengaruh terhadap manajemen laba. Dengan demikian, untuk penelitian selanjutnya dapat menggunakan proksi lain untuk mempresentasikan elemen-elemen pada teori kecurangan.

Keterbatasan penelitian juga terdapat pada penggunaaan metode kuantitas dalam pengukuran masing-masing variabel. Penelitian ini juga berfokus pada satu industri pembiayaan sehingga tren dari masing-masing industri dapat dibedakan satu dengan yang lainnya.

Saran untuk penelitian selanjutnya diantaranya adalah Penambahan jumlah observasi dan rentang waktu periode penelitian agar didapat hasil yang maksimal dalam melihat pengaruh dari masing-masing elemen Fraud Diamond. Selain itu penelitian ini juga dapat diadopsi untuk melihat fenomena serupa pada sektor industri lainnya, baik yang terdaftar dalam BEI ataupun tidak.

\section{REFERENCES}

ACFE, (2018). Report to The Nation on Occupational Fraud and Abuse (On-line). Diakses 14 Juni 2019

Beasley, M., \& Salterio, S. (2001). The relationship between board characteristics and voluntary improvements in the capability of audit committees to monitors. Contemporary Accounting Research, 18(4).

Beneish, Messod. (1999). The Detection of Earning Manipulation. Financial Analysis Journal. Vol 55, No. 5.

Cressey, D. (1953). Other People's Money: A Study In The Social Physhology Of Embezzlement. IL: Free Press
Dechow, P., Sloan, R. \& Sweeney, A. (1995).Detecting earning management. The Accounting Review.

Dorminey, J., Fleming, A. S., Kranacher, M. J., \& Riley, R. A. (2012). The evolution of fraud theory. Issues in Accounting Education, 27(2), 555-579.

Farvaque, E., Refait-alexandre, C., \& Saïdane, D. (2012). Corporate Disclosure: A Review Of Its ( Direct And Indirect ) Benefits And Costs. International Economics, 128 (2011).

Francis, J. R., and Krishnan, J. (1999). Accounting accruals and auditor reporting conservatism.Contemporary Acconting Research, $16(1)$.

Francis, J. R. (2004). What do we know about audit quality?. The British AccountingReview, 36 (4).

Hogan, C. E., Rezaee, Z., Riley, R. A., \& Velury, U. K. (2008). Financial statement fraud: Insights from the academic literature. Auditing, 27(2).

Healy, P. M., \& Palepu, K. G. (2001). Information asymmetry, corporate disclosure, and the capital markets: A review of the empirical disclosure literature.

Healy, P. M., \& Wahlen, J. M. (1999). A Review of the Earnings Management Literature and Its. Accounting Horizons, 13(4).

Jensen, M. \& Meckling, W. (1976). Theory Of The Firm: Managerial Behavior, Agency Costs And Ownership Structure. Journal of Financial Economics, 3(4).

Lennox, C., Pittman, J. (2010). Big Five Audits and Accounting Fraud. Contemporary Accounting Research, Vol 27, No1.

Leuz, C., Nanda, D. Wysocki, P.D. (2003). Earnings Management and Investor Protection: An International Comparison. Journal of Financial Economics, Vol. 69. No. 3.

Loebbecke, J., Eining M., and Willingham J. (1989). Auditor's Experience With Material Irregularities : Frequency, Nature, and Detestability. $A u-$ diting: A Journal Of Practice and Theory, 9(1).

Lou, Y. I., \& Wang, M. L. (2009). Fraud Risk Factor of The Fraud Triangle Assesing The Likelihood of Fraudulent Financial Reporting. Journal of Business and Economic Research.

Oktarigusta, Lutfianan. 2016. Analisis Fraud Diamond untuk Mendeteksi terhadinya Financial 
Statement Fraud di Perusahaan (Studi Empiris pada

Perusahaan Manufaktur yang Terdaftar di BEI Tahun 2012- 2015). Universitas Muhammadiyah Surakarta, p. 1-13.

Rezaee, Z. (2002). "Financial Statement Fraud: Prevention and Detection". New York: John Wiley \&Sons, Inc.Sons, Inc.

Ruankaew, T. (2016). Beyond the Fraud Diamond. International Journal of Business Management \& Economic Research, 7(1), 474-476.

Schipper, K. 1989. Commentary on earnings management. Accounting Horizons (December): 91-102.

Scott, W. (2009). Financial Accounting Theory.Toronto: Prentice Hall

Skinner, D. J., \& Dechow, P. M. (2000). Earnings Management: Reconciling the Views of Accounting Academics, Practitioners, and Regulators. Accounting Horizons, 14(2).

Skousen, C. J., Smith, K. R., \& Wright, C. J. (2008). Detecting and predicting financial statement fraud: the effectiveness of the fraud traingle and, (99).Corporate Governance and Firm Performance Advance in Financial Economincs, Vol. 13.

Statement of Auditing Standards (SAS) No.99 Tahun 2002

Stice, J.D. (1991). Using Financial and Market Information to Identify Preengagements Factors Associated with Lawsuits Against Auditors. The Accounting Review (July).

Summers, S. L., \& Sweeney, John, T. (1998). 1998 Fraudulently Misstated Financial Statements and Insider Trading copy. The Accounting Review, 73(1), 131-146.

Tessa, Chyntia G.,Puji Harto. (2016). Fraudulent Financial Reporting: Pengujian Teori Fraud Pentagon Pada Sektor Keuangan Dan Perbankan Di Indonesia. Simposium Nasional Akuntansi XIX, Lampung

Tiffani, Laila and Marfuah. (2015). Deteksi Financial Statement Fraud Dengan Analisis Fraud Triangle Pada Perusahaan Manufaktur Yang Terdaftar Di Bursa Efek Indonesia.Indonesian Journal of Accounting and Auditing, 2015 No. 2(Desember): 112-25.

Wolfe, David T, and Dana R. Hermanson. (2004). The Fraud Diamond: Considering The Four 